\title{
ASSESSING PHARMACY STUDENTS' MIGRATION RELATED ATTITUDES AND INTENTION TO EMIGRATE FROM LITHUANIA
}

\author{
Gvidas Urbonas ${ }^{1}$, Indrẻ Venclovaitė ${ }^{2}$, Aušra Urbonien $\dot{e}^{3}$, Loreta Kubilien $\dot{e}^{4}$ \\ ${ }^{1}$ Department of Social Sciences and Humanities, Lithuanian University of Health Sciences, Kaunas, \\ Lithuania, ${ }^{2}$ Faculty of Pharmacy, Lithuanian University of Health Sciences, Kaunas, Lithuania \\ ${ }^{3}$ Department of Philosophy and Psychology, Kaunas University of Technology, Kaunas, Lithuania \\ ${ }^{4}$ Department of Drug Technology and Social Pharmacy, Lithuanian University of Health Sciences, \\ Kaunas, Lithuania
}

Key words: migration, reasons for emigration, intention to emigrate, pharmacy students.

\begin{abstract}
Summary
Lithuania among the middle-income countries is experiencing the brain drain situation when high-educated professionals, including health care specialists, migrate to high-income countries in search for better economic, social and cultural life. The objective of the study was to identify the potential reasons for migration from the perspective of pharmacy students that might come into consideration after they graduate university. A convenience sample $(n=196)$ of pharmacy students participated in the cross-sectional survey where they gave opinion on why people emigrate from Lithuania, also expressed personal attitude towards emigration, as well as intention to emigrate after the studies on self-report scales. The nonlinear Robust Path Analysis approach was employed for data analysis. The results revealed that high unemployment conceived as a reason to emigrate from Lithuania, as well as personal attitude towards emigration was significantly linked with intent to emigrate after studies. Family or friends living abroad, adverse cultural environment, and lack of entertainment options conceived as a reason to emigrate significantly affected students personal attitude towards emigration from Lithuania. High unemployment as a reason for emigration remained the main factor directly associated with the intention to emigrate. However, investment in social, cultural and human capital should be seen as the next step to reduce the attractiveness of emigration to the future pharmacists.
\end{abstract}

\section{Introduction}

After the labour market of the European Union became open to migrants from the new EU countries, a significant increase in migration flows from middle-income countries was observed. Lithuania is named as one of the EU "sending countries"[1] with young citizens being among the most mobile persons: every second migrant from Lithuania was 20-34 years old during 2012-2015 [2].

The major disadvantage of international migration is that low- and middle-income countries get into the brain drain situation. They act as donors of high-educated people to the wealthier states and experience social and fiscal losses that hinder their growth [3-5]. The European Commission estimates a potential shortfall of around 1 million healthcare workers by 2020 among which 150.000 of dentists, pharmacists and physiotherapists not covering $13.5 \%$ of health care [6]. While the phenomenon may seem to benefit individual, it may catalyse social inequality [7] and hamper the provision of adequate health care in the donor nations [8]. Brain drain is also determined by the hegemonic advantage of the high-developed countries that set standards for study quality: the developing countries trying to adapt their curricula to the standards of the high-developed states simultaneously produce workforce for the wealthier states [9].

Multiple theories have been developed to explain the phenomenon of migration [10-12] and a number of factors have been discovered that push or pull people to move abroad [3,13-18].

The aim of the study was to re-examine which of the reasons for emigration that were identified in previous theoretical and empirical studies significantly affected pharmacy students' personal attitude towards emigration and intent to emigrate from Lithuania. To reach the goal, two main 
objectives were formulated: (a) to analyse pharmacy students' opinions towards the reasons for emigration and (b) to assess which of the conceived reasons for emigration are significantly related with personal attitude towards emigration and intention to emigrate after the studies.

\section{Methods}

At the initial stage of the questionnaire development process ten pharmacy students were invited to participate in a focus-group discussion conducted in February, 2013 [19]. Based on the results of the focus-group research, as well as analysis of scientific literature $[3,13-18]$ a questionnaire was developed to evaluate students' opinions about the main reasons for emigration, and to estimate their personal attitude towards emigration and intent to leave the country after the studies.

The survey was conducted in 2014 . The population consisted of 487 pharmacy students studying at the Lithuanian University of Health Sciences - the only higher school that educated pharmacists in Lithuania. The convenience sampling method was used to reach the goals of the study. During the research, a total of 250 questionnaires were distributed to the students and 206 of them were received $(82.4 \%$ response rate). 10 questionnaires (4.9\%) with missing answers were excluded from further analysis. After exclusion, a total of 196 questionnaires were selected for data analysis. Three quarters $(74.0 \%)$ of the respondents were females. One third $(31.6 \%)$ of the students reported that some of their family members were living abroad and 39.7 percent of the respondents had gained some work experience abroad themselves. Among the students who intended to emigrate, $19.2 \%$ planned to leave the country for less than two years, $57.7 \%$ of them planned to emigrate for more than 2 years, and $23.1 \%$ planned to stay abroad permanently. All the students who had plans to emigrate were going to work as pharmacists abroad. The socio-demographic variables were also included in the path analysis to control the effects of gender, study year, provenance, previous work experience gained abroad, and country of destination in the final model.

The data were analysed using the Robust path analysis method [20]. The method is understood as a ",pure' path analysis, where all latent variables are measured through one single formative indicator" [21:118] as was our case. The validity of the data was estimated with the Stone-Geisser Q-squared coefficients, as well as block and full collinearity variance inflation factors. The degree of vertical collinearity was assessed by calculating block variance inflation factors for each variable with two or more predictors. Full collinearity variance inflation factors were calculated simultaneously for all the variables to assess for lateral collinearity in the model [22].
Non-linear multivariate statistical analysis software WarpPLS 5.0 [23] was used for data analysis. The software allowed us to conduct the Robust path analysis whereby $\mathrm{P}$ values were calculated through the jacknife resampling technique. Direct and indirect coefficients of association were calculated together with their respective P-values, as well as Cohen's f-squared effect sizes. In addition, an exploratory nonlinear analysis was conducted to investigate the possibility that the relationships among the variables conformed to noncyclical nonlinear functions [20,23].

To test the model for mediations, an algorithm described by Hair et al. was applied. The type of the mediation was identified by estimating the size of indirect effect in relation to the total effect, i.e., the proportion of variance accounted for (VAF) was calculated [24].

\section{Results}

Respondents were asked to express their personal attitude towards emigration and intention to emigrate after the studies. A half of the students (52\%) expressed a positive attitude towards emigration, while one third (32.1\%) of respondents saw emigration as a negative phenomenon (Table 1).

Despite the majority of the respondents viewed emigration positively, only $13.3 \%$ had plans to leave the country after their studies. The students were also asked to express their opinion on the reasons for emigration from Lithuania (Table 1). The majority of the students thought that people emigrate due to low wages and better job perspectives abroad (mode $=5$ ). Among the reasons that, in students' opinion, promote emigration least were low-quality health care, insufficient leisure and entertainment options, and unfriendly physical environment (mode $=2$ ).

Further step of data analysis was to test which of the conceived Reasons for Emigration (RE) significantly affected students' Personal Attitude towards Emigration (PAtE) and Intention to Emigrate (ItE). To reach the goal, a model was created with all exogenous variables of RE pointing towards the endogenous variables of PAtE and ItE. Also the sociodemographic data were included as control variables on PAtE and ItE. Further, all non-significant paths were removed stepwise backwards and the final model with significant paths was tested for validity again (Figure 1).

The Stone-Geisser Q-squared coefficient values for both PAtE $\left(Q^{2}=0.37\right)$ and ItE $\left(Q^{2}=0.21\right)$ showed sufficient predictive validity of the model. Block variance inflation factors and full collinearity inflation factors of all the indicators were below the threshold of 3.3 [22]. It allowed us to conclude that the model was free from both vertical and lateral collinearity and the results of our analysis were not biased by the model-wide multicollinearity.

Exploratory non-linear analysis was conducted to in- 
Table 1. Descriptive statistics

Notes: $M o$ - mode, $M$ - mean, $S D$ - standard deviation;

a Three-point scale ranging from 1 (Negatively) to 3 (Positively);

${ }^{b}$ Five-point scale ranging from 1 (Strongly Disagree) to 5 (Strongly Agree);

${ }^{c}$ Three-point scale ranging from 1 (No) to 3 (Yes).

\begin{tabular}{|l|c|c|c|c|c|}
\hline $\begin{array}{l}\text { PAtE: How do you personally view } \\
\text { the phenomenon of emigration from } \\
\text { Lithuania? }\end{array}$ & $\begin{array}{c}\text { Positi- } \\
\text { vely (\%) }\end{array}$ & $\begin{array}{c}\text { Negati- } \\
\text { vely (\%) }\end{array}$ & Mo & M & SD \\
\cline { 2 - 6 } & 52.0 & 32.1 & 3 & 2.20 & 0.90 \\
\hline $\begin{array}{l}\text { RE: Which, of the listed below, in your opi- } \\
\text { nion, are the main reasons for emigration } \\
\text { from Lithuania? }\end{array}$ & $\begin{array}{c}\text { Agree } \\
\mathbf{( \% )}\end{array}$ & $\begin{array}{c}\text { Disagree } \\
\mathbf{( \% )}\end{array}$ & & & \\
\hline RE1: Low wages & 96.9 & 1.5 & 5 & 4.67 & 0.61 \\
\hline RE12: Better job opportunities abroad & 90.8 & 9.2 & 5 & 4.36 & 0.81 \\
\hline RE6: High unemployment rate & 76.5 & 12.7 & 4 & 4.00 & 1.02 \\
\hline RE2: Heavy taxes & 70.4 & 4.6 & 4 & 3.98 & 0.87 \\
\hline $\begin{array}{l}\text { RE5: Poor socio-economic status of the fa- } \\
\text { mily }\end{array}$ & 71.5 & 12.7 & 4 & 3.81 & 0.97 \\
\hline RE3: High product prices & 71.5 & 14.8 & 4 & 3.80 & 0.96 \\
\hline RE11: Low opportunities to start a business & 67.4 & 11.2 & 4 & 3.80 & 0.93 \\
\hline RE13: Family or friends living abroad & 65.8 & 14.3 & 4 & 3.62 & 0.97 \\
\hline RE4: Poor living conditions & 53.6 & 25.0 & 4 & 3.41 & 1.02 \\
\hline RE10: Low-quality education & 43.9 & 33.7 & 4 & 3.20 & 1.06 \\
\hline RE7: Social and physical insecurity & 39.8 & 29.1 & 4 & 3.14 & 0.94 \\
\hline RE15: Adverse cultural environment & 21.9 & 38.3 & 3 & 2.84 & 0.92 \\
\hline RE9: Low-quality health care & 18.4 & 57.7 & 2 & 2.57 & 0.94 \\
\hline $\begin{array}{l}\text { RE14: Insufficient leisure and entertainment } \\
\text { options }\end{array}$ & 12.7 & 63.8 & 2 & 2.39 & 0.89 \\
\hline $\begin{array}{l}\text { RE8: Unfriendly physical environment (cli- } \\
\text { mate, pollution, etc.) }\end{array}$ & 13.8 & 73.0 & 2 & 2.20 & 1.02 \\
\hline & Yes (\%) & No (\%) & & & \\
\hline $\begin{array}{l}\text { ItE: Do you plan to emigrate after the } \\
\text { studies? }\end{array}$ & 13.3 & 41.8 & 2 & 1.71 & 0.68 \\
\hline WExp: Have you ever worked abroad? & 39.7 & 60.3 & & & \\
\hline
\end{tabular}

vestigate the possibility that the relationships among the variables conformed to nonlinear functions $[20,23]$. The results showed that the use of the non-linear algorithm (Warp 3) [23] increased path coefficients' strengths (absolute $\beta$ values) and variances explained (R-squared coefficients), also multicollinearity decreased slightly. Given these outcomes, an assumption was made that nonlinear functions better reflected the nature of the relationships among the variables.

The results of the path analysis (Fig. 1) showed that Intention to Emigrate was moderately affected by Personal Attitude towards Emigration (Fig. 2).

Among the conceived Reasons for Emigration, four of them were significantly associated with either Personal Attitude towards Emigration or Intent to Emigrate (Fig. 3).

Among the socio-demographic characteristics, Previous Work Experience Abroad had small significant direct effects on both Personal Attitude towards Emigration and Intention to Emigrate (Fig. 4).

The variables that directly affected Personal Attitude towards Emigration also showed indirect effects on Intention to Emigrate. Yet the effects appeared to be too small to be considered as relevant ones. The variable of Work Experience had not only a significant direct effect on respondents' Intention to Emigrate, but the effect also appeared to be partially mediated by the Personal Attitude towards Emigration (VAF=32\%; $\mathrm{f}^{2}=0.08$ ).

Since we controlled for the effects of the sociodemographic variables with respect to PAtE and ItE, we can say that the findings summarized above hold regardless of variations in those variables [20], because all the paths remained significant after the control variables were included in the model.

\section{Discussion}

Scientific literature on migration finds migrant friends and/or relatives to be a strong pulling force for people to emigrate [25-27]. The results of our study revealed that students who either strongly agreed or disagreed with the statement viewed emigration as an attractive phenomenon (RE13 on PAtE; Figure 1), while respondents who had no opinion on the question expressed rather neutral attitude towards emigration. The non-linear relationship probably might be explained with the theory of intergenerational relationships [18]: the students who had intimate-but-distant relationships with their families imagined migration as living apart from migrant relatives and, on the other side, respondents who had tight-knit relationships with their families saw emigration as an opportunity to join migrant friends or relatives. However, the hypothesis has to be tested in future research.

Some studies found that high skilled professionals, including pharmacists [27], the so called "creative class" [28] migrate for lifestyle reasons to satisfy increased needs in the global world $[15,29,30]$. Our study revealed that young people who were fully satisfied with the current range of leisure and entertainment services (RE14 on PAtE; Figure 1) had a slightly negative personal attitude towards emigration. However, the attractiveness of emigration started increasing with increase in agreement that people emigrate in seek for more entertaining life. Higher accessibility in 
quality and quantity of entertainment services for students and, consequently, for future professionals may be seen as an effective means to reduce attractiveness of emigration.

Belief that people leave Lithuania due to adverse cultural environment (RE15 on PAtE; Figure 1) was found to have a linear impact on personal perception of emigration. Students who did not feel being part of the current culture, felt not socialized enough saw emigration as a way of changing cultural environment. Similarly, negative attitudes towards the home country environment were found to be associated with intentions to emigrate mostly for long term among the final year pharmacy students from nine countries [31].

Respondents with previous work experience abroad (WExp) saw emigration as a positive phenomenon, but expressed rather neutral propensity to emigrate (Figure 2). Meanwhile, the students without work experience gained

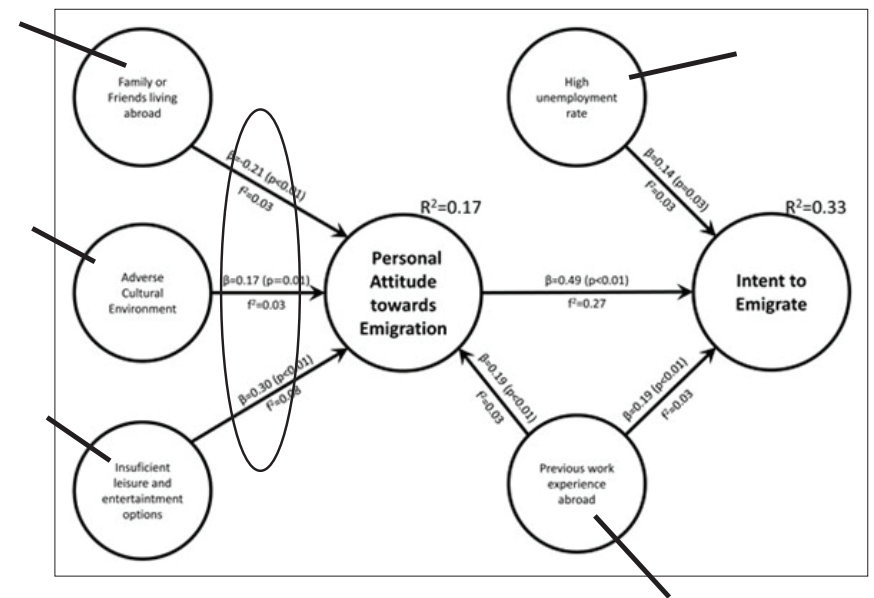

Fig. 1. The final model of the relationships among the opinions about the Reasons for Emigration, Work Experience gained Abroad, Personal Attitude towards Emigration, and Intention to Emigrate.

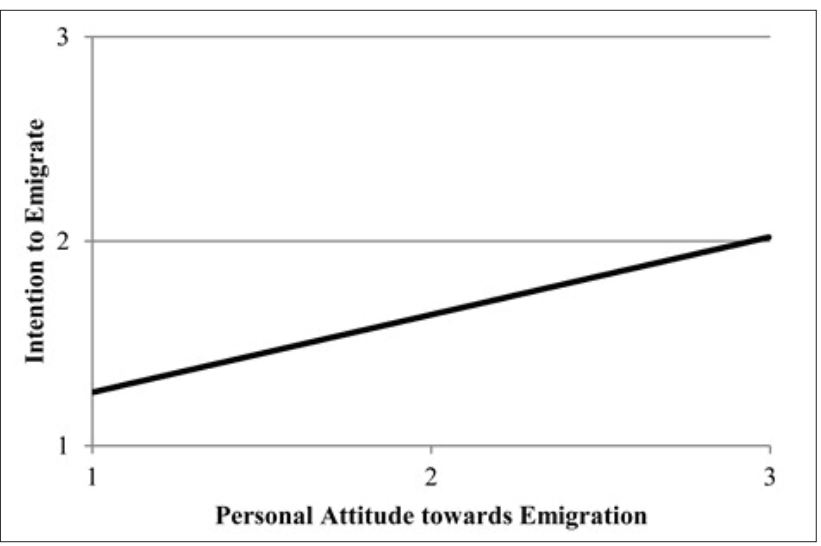

Fig. 2. Relationship between Personal Attitude towards Emigration and Intention to Emigrate. abroad expressed neutral opinion on emigration and were less likely to emigrate. Similarly, a study conducted by Wuliji, et al. [31] found that final year pharmacy students with past pharmacy experience abroad expressed intentions to emigrate for mostly long term.

Personal attitude towards emigration appeared to have the strongest effect on students' intention to leave the country after the studies (Figures 1 and 3): the more negative personal attitude towards emigration they had, the lower propensity for emigration was expressed. The result offers an insight that positive perception of emigration does not necessarily result in backpacking. Rather, the variable of Personal Attitude towards Emigration appeared to be the variable that predicted intention not to emigrate. Probably the so called "stick factors" or bariers for emigration played role in the relationship that should be explored in future research.

Belief that people emigrate from Lithuania due to high

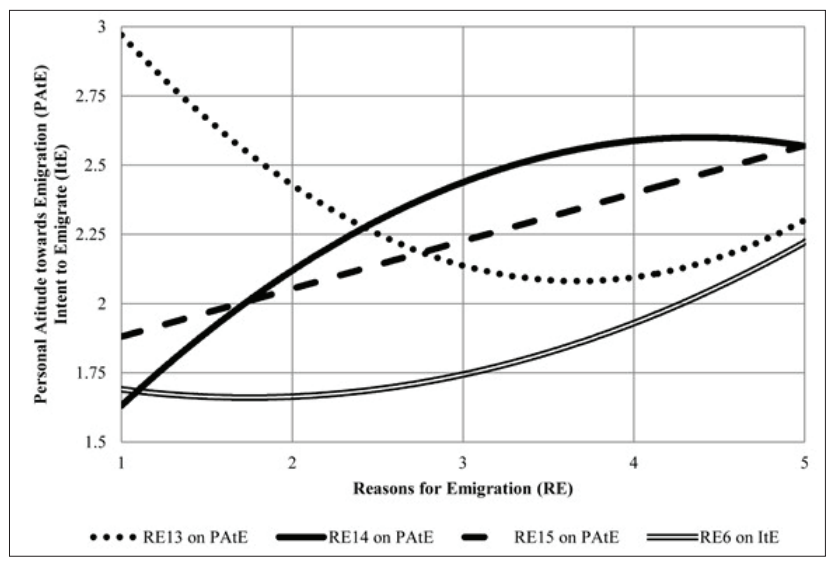

Fig. 3. Relationships between Reasons for Emigration and Personal Attitude towards Emigration, as well as Intention to Emigrate.

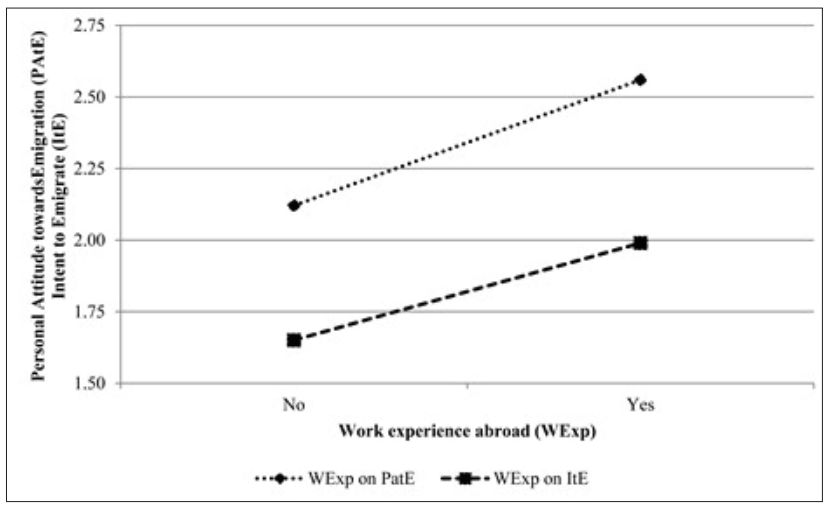

Fig. 4. Relationships between Work Experience abroad (WExp) and Personal Attitude towards Emigration (PAtE), as well as Intention to Emigrate (ItE). 
unemployment was the only reason for emigration that was positively linked with emigration plans. Respondents who did not conceive high unemployment (RE6 on ItE; Figure 1) as a reason for emigration expressed comparatively low intentions to emigrate. Meanwhile, the more students recognized that high unemployment pushes people abroad, the more they were likely to consider emigration as a possible outcome. The finding is consistent with the results from multiple studies that found high unemployment as one of the main causes of emigration from Lithuania $[15,17,32]$. Consistently, the proportion of students who intended to emigrate from Lithuania was smaller as compared to pharmacists, where more than one quarter expressed wishes to work in other EU countries in 2004 [25]. The result means that despite the fact that migration flow rates had remained high, the absolute majority of respondents tended to start their professional carreer in Lithuania. However, we should keep in mind that more than a half of the respondents saw emigration as a positive phenomenon and, as the path analysis showed, would consider leaving the country in case of unemployment.

The implications following from the results are that reduction of unemployment is to be among the main tools to reduce pharmaceutical brain drain. Nevertheless, as Kazlauskienè and Rinkevičius state, even significant improvement of socioeconomic and professional conditions in Lithuania will not stop the brain drain as long as the quality of life stays relatively higher in foreign countries [33]. Scarcity of high quality leisure and entertainment options for the educated youth, adverse cultural environment were found to exist as potential risks that would make emigration more inviting and, if not coped with, have potential to be included among the main reasons for emigration in the near future. Local and national governments, therefore, should focus not only on employment policies, but also invest in social, cultural and human capital in order to reduce the attractiveness of emigration and keep the qualified youth in Lithuania. Next, we should keep in mind that only $17 \%$ in the variance of the variable of Personal attitude towards emigration and 33\% in the variance of the variable of Intent to Emigrate were explicable under the model (Figure 1). It means that the list of the common reasons for emigration that were re-examined in our study is not sufficient enough to fully grasp what makes emigration attractive to pharmacy students. Additional theoretical and/or empirical studies should be conducted to explore additional intrinsic or extrinsic factors different from those examined in our study.

\section{Conclusion}

Although, Lithuanian pharmacy students viewed the phenomenon of emigration positively, they were rather unenthu- siastic about leaving their homeland after the studies. Since the minority of the conceived reasons for emigration included in our study significantly affected respondents ' personal attitude towards emigration and intent to emigrate, additional theoretical and/or empirical studies should be conducted in the future to uncover the "hidden" factors that significantly affect students' intent to emigrate from Lithuania.

\section{References}

1. Heikkilä E. Migration and labour market integration in the Baltic sea region: an emphasis on Finland. In: Liutho K, editor. The Baltic Sea region: ten policy-oriented articles from scholars of the University of Turku. Turku: Centrum Balticum, 2014; 75-87.

2. Statistics Lithuania. 2016. Available from: http://osp.stat.gov. 1t/en/temines-lenteles1 (cited 01.11.2016).

3. Verkhohlyad O, McLean G. Applying organizational commitment and human capital theories to emigration research. Eur J Train Dev. 2012;36(2/3):308-328.

https://doi.org/10.1108/03090591211204760

4. Cattaneo C. International migration, the brain drain and poverty: a cross-country analysis. World Econ 2009; 32(8):1180-1202. https://doi.org/10.1111/j.1467-9701.2009.01178.x

5. Nica $E$. The causal impact of brain drain migration on economic development. Contemp Read Law Soc Just 2013; 5(1):94-99.

6. European Commission. Commission Staff Working Document on an Action Plan for the EU Health Workforce. Strasbourg: European Commission; 2012. Available from: http://ec.europa. eu/health/workforce/docs/staff_working_doc_healthcare_workforce_en.pdf.

7. Docquier F, Rapoport H. Globalization, brain drain, and development. J Econ Lit 2012; 50(3):681-730.

https://doi.org/10.1257/jel.50.3.681

8. Hawthorne N, Anderson C. The global pharmacy workforce: a systematic review of the literature. Hum Resour Health. 2009;7(48). doi: 10.1186/1478-4491-7-48.

https://doi.org/10.1186/1478-4491-7-48

9. Matowe L, Duwiejua M, Norris P. Is there a solution to the pharmacist brain drain from poor to rich countries? Pharm J 2004; 272(7283):98-99.

10. Massey D, Arango J, Hugo G, Kouaouchi A, Pellegrino A, Taylor J. Theories of international migration: a review and appraisal. Popul Dev Rev 1993; 19(3):431-66. doi: 10.2307/2938462. https://doi.org/10.2307/2938462

11. De Haas H. Migration and development: a theoretical perspective. Int Migr Rev 2010; 44(1):227-64. doi: 10.1111/j.17477379.2009.00804.x. https://doi.org/10.1111/j.1747-7379.2009.00804.x

12. Garip F. Social capital and migration: how do similar resources lead to divergent outcomes? Demography 2008; 45(3):591-617. doi: 10.1353/dem.0.0016.

https://doi.org/10.1353/dem.0.0016

13. Bueno de Mesquita J, Gordon M. The international migration 
of health workers: a human rights analysis. London. Medact 2005.

14. Kumpikaite V, Žičkute I. [Analysis of factors that affect emigration]. Economics and Management 2012;17(2):740-746. doi: 10.5755/j01.em.17.2.2207. Lithuanian https://doi.org/10.5755/j01.em.17.2.2207

15. Kumpikaite V, Zickute I. Regression analysis of economic factors influencing emigration rate in Lithuania. Procedia Soc Behav Sci 2013;92. doi: 10.1016/j.sbspro.2013.08.701. https://doi.org/10.1016/j.sbspro.2013.08.701

16. Janusauskas A, Tumas V. Medical professional's emigration: causes and the consequences. Eur Sci J 2014;10(8):47-58.

17. Dapkus M, Matuzevičiūtè K. Expectations influence on emigration: Lithuanian case. Economics and Management 2008;13:343-349.

18. Juozeliūnienė I, Tureikytė D, Žilinskienė L, Butènaitė R, Novikas S. Emigrants: 'excluded' or the new social agents? Filosofija. Sociologija, 2014; 25(4):254-262.

19. Kuršelis V, Venclovaitė I, Kubilienė L. Lithuanian University of Health Sciences Medical Academy Pharmacy Faculty students evaluation of employment expectations and migration. In: 73rd World Congress of Pharmacy and Pharmaceutical Sciences, 31 August-5 September Dublin; 2013.

20. Kock N, Gaskins L. The mediating role of voice and accountability in the relationship between internet diffusion and government corruption in Latin America and SubSaharan Africa. Inf Technol Dev 2014;20(1):23-43. doi: 10.1080/02681102.2013.832129.

https://doi.org/10.1080/02681102.2013.832129

21. Kock N. Interdisciplinary applications of electronic collaboration approaches and technologies. Hershey, PA: IGI Global; 2013. https://doi.org/10.4018/978-1-4666-2020-9

22. Kock N, Lynn G. Lateral collinearity and misleading results in variance-based SEM: an illustration and recommendations. J Assoc Inf Sys 2012;13(7):546-580.

23. Kock N. WarpPLS 5.0 user manual. Laredo, Texas: ScriptWarp Systems 2015.

24. Hair J, Hult G, Ringle C, Sarstedt M. Primer on Partial Least Squares Structural Equation Modeling (PLS-SEM). Thousand Oaks, CA: SAGE Publications 2014.

25. Šmigelskas K, Starkiene L, Padaiga Z. Do Lithuanian pharmacists intend to migrate? J Ethn Migr Stud 2007;33(3):501-509. https://doi.org/10.1080/13691830701234814

26. Sharma A, Lambert T, Goldacre M. Why UK-trained doctors leave the UK: cross-sectional survey of doctors in New Zealand. J R Soc Med 2012;105(1):25-34. https://doi.org/10.1258/jrsm.2011.110146

27. Hassell K, Nichols L, Noyce P. Part of a global workforce: migration of British-trained pharmacists. J Health Serv Res Policy 2008;13(2). https://doi.org/10.1258/jhsrp.2007.007100

28. Florida R. The flight of the creative class: the new global competition for talent. New York. Harper Collins, 2010.

29. Rakauskienè O, Ranceva O. Threat of emigration for the socioeconomic development of Lithuania. Business, Management and Education 2013;11(1):77-95.

https://doi.org/10.3846/bme.2013.05

30. Isański J, Mleczko A, Seredyńska-Abou Eid R. Polish contemporary migration: from co-migrants to project ME. Int Migr 2014;52(1):4-21. doi: 10.1111/imig.12076.

https://doi.org/10.1111/imig.12076

31. Wuliji T, Carter S, Bates I. Migration as a form of workforce attrition: a nine-country study of pharmacists. Hum Resour Health 2009;7(32). doi: 10.1186/1478-4491-7-32.

https://doi.org/10.1186/1478-4491-7-32

32. Dudzevičiūtė G, Čekanauskas J. The research of the causal relationship between unemployment and emigration in Lithuania. Business: theory and practice. 2014;15(4):294-301. doi: 10.3846/btp.2014.516.

https://doi.org/10.3846/btp.2014.516

33. Kazlauskienè A, Rinkevičius L. Lithuanian 'brain drain' causes: push and pull factors. Engineering Economics 2006;1(46):27-37.

\section{FARMACIJOS STUDENTU POŽIŪRIO I EMIGRACIJA IR KETINIMO EMIGRUOTI IŠ LIETUVOS VERTINIMAS}

\section{G. Urbonas, G. Venslauskaitè, A. Urbonienè, L. Kubilienè}

Raktažodžiai: migracija, emigracijos priežastys, ketinimas emigruoti, farmacijos studentai.

Santrauka

Lietuva, kaip ir kitos vidutinio išsivystymo šalys, patiria ,protų nutekejjimo" problemą, kai aukštajị išsilavinimą turintys profesionalai, ịskaitant sveikatos priežiūros specialistus, migruoja ị išsivysčiusias šalis dèl geresnio ekonominio, socialinio ir kultūrinio gyvenimo. Šio tyrimo tikslas - identifikuoti potencialias emigracijos priežastis, kurios farmacijos studentams taps aktualios baigus universitetą. Rezultatai atskleidè, kad aukštas nedarbo lygis, taip pat asmeninis požiūris ị emigraciją buvo tiesiogiai susiję su ketinimu emigruoti po studijų. Tačiau asmeniniam farmacijos studentu požiūriui ị emigraciją reikšmingos ịtakos turèjo ịsitikinimas, kad žmonès iš Lietuvos išvyksta dèl užsienyje gyvenančių šeimos narių ar draugų, neigiamos kultūrinès aplinkos, nepakankamo laisvalaikio pramogų pasirinkimo. Taigi, nors nedarbo mažinimas išlieka prioritetine emigracijos mažinimo sritimi, didesnès investicijos i socialinị, kultūrinị ir žmogiškajị kapitalą galètų prisidèti mažinant emigracijos patrauklumą būsimiems vaistininkams.

Adresas susirašinèti: gvidas.urbonas@gmail.com Gauta 2017-04-24 